\title{
Sudden changes in volatility: The case of five central European stock markets
}

\author{
Ping Wang ${ }^{a^{*}}$, Tomoe Moore ${ }^{b}$ \\ ${ }^{a}$ Birmingham Business School, University of Birmingham, Edgbaston, \\ Birmingham B15 2TT, United Kingdom \\ ${ }^{b}$ Department of Economics and Finance, Brunel University \\ Uxbridge, Middlesex, UB8 3PH \\ United Kingdom
}

This version: 24 May 2007

\begin{abstract}
This paper investigates sudden changes in volatility in the stock markets of new European Union (EU) members by utilizing the iterated cumulative sums of squares (ICSS) algorithm. Using weekly data over the sample period 1994-2006, the time period of sudden change in variance of returns and the length of this variance shift are detected. A sudden change in volatility seems to arise from the evolution of emerging stock markets, exchange rate policy changes and financial crises. Evidence also reveals that when sudden shifts are taken into account in the GARCH models, the persistence of volatility is reduced significantly in every series. It suggests that many previous studies may have overestimated the degree of volatility persistence existing in financial time series.

JEL classification: G15; F02
\end{abstract}

Keywords: Stock return volatility; Iterated Cumulative Sums of Squares algorithm; Emerging stock markets; GARCH

* Corresponding author. Tel.: +44 121414 6675; fax: +44 1214146638.

E-mail addresses: p.wang.1@bham.ac.uk (P.Wang), tomoe.moore@brunel.ac.uk

(T. Moore) 


\section{Introduction}

In this paper we examine sudden changes of volatility in the stock markets of new EU members, which were experienced during the transition period from command to market economy and during the period of integration into the EU. Theory suggests that structural changes in fundamentals are associated with the changes in the behaviour of stock markets, since stock prices theoretically reflect expectations of future dividends, interest rates and risk premia, which in turn depend on macroeconomic conditions. It follows that both first and second moments of stock returns should be affected during the process of transition and integration of these economies to the extent that it affects fundamentals (Morana and Beltratti, 2002). The transition of economic systems followed by the currently on-going process of economic integration within the EU may have considerably affected the fundamentals in the new EU member states. Given the existing empirical literature on the shift in the stock market on such occasions ${ }^{1}$, it is worthwhile addressing the issue of the pattern of volatility in stock returns for the new EU member states.

Time varying volatility of stock returns has been extensively modelled by the GARCH with high frequency stock data to find high persistence in volatility. The GARCH approach assumes that there is no shift in volatility; however, in such emerging markets there may potentially be sudden shifts in volatility. It is therefore important to take account of these shifts in estimating volatility persistence. In this paper, the shifts in volatility are identified by utilising the iterated cumulative sums of squares (ICSS)

\footnotetext{
${ }^{1}$ For example, Westermann (2004) empirically showed that the introduction of the euro shifted the linkage of stock returns across the eurozone stock markets. Kim et al. (2005) find that increased stability and higher levels of integration have emerged from the European Monetary Union in the post-euro era.
} 
algorithm of Inclan and Tiao (1994). The GARCH model is then estimated by taking account of the volatility shifts. The ICSS endogenously identifies changes in volatility of stock returns. The technique is not much explored in empirical analysis of stock markets. Aggarwal et al. (1999) examined emerging stock markets in Asia and Latin America, and recently Hammoudeh and Li (2006) investigated the sudden changes in volatility for the volatile Gulf Arab stock markets ${ }^{2}$. This paper is the first to investigate transition economies using this technique.

Specifically, we investigate the emerging stock markets of the Czech Republic, Hungary, Poland, Slovakia and Slovenia over the period 1994-2006. Our empirical results indicate that a sudden change in volatility seems to arise from the evolution of emerging stock markets in an earlier period, from exchange rate policy changes and financial crises. Evidence also reveals that when sudden shifts are taken into account in the conventional GARCH models, the persistence of volatility is reduced significantly in every series. It suggests that many previous studies may have overestimated the degree of volatility persistence that exists in financial time series.

The remainder of the paper is organised as follows. In Section 2, potential factors for the shifts in volatility are briefly discussed, which rationalises the usefulness of the current study. Methodology and data are described in Sections 3 and 4 respectively. In Section 5, the result of the ICSS algorithm and GARCH model are presented. Section 6 will conclude.

\section{Volatility of the stock markets of transition economies}

\footnotetext{
${ }^{2}$ The ICSS algorithm is also applied to foreign exchange markets by Malik (2003) and large and small capitalization stocks by Ewing and Malik (2005).
} 
In this section, potential internal and external factors for sudden changes in volatility of these stock markets are briefly discussed ${ }^{3}$.

Stock markets are not new in these transition economies. The Warsaw Stock Exchange was opened in 1817 and the Prague Stock Exchange in 1971, although all stock markets were closed during the socialist period. During the transition from command to market economies, stock exchanges re-emerged with mass privatization programmes in the early 1990s. This earlier stage of the stock market was characterised by the lack of an adequate regulatory framework and the dominance of a small number of companies. There was also less incentive for companies to list due to both the requirement of disclosure and the high cost of raising funds through the market compared with bank credit. Moreover, during 1994-1999 the return on stock market investments in transition economies was often negative on a risk-adjusted basis, thus bank deposits outperformed stock market returns. This was exacerbated by relatively high inflation. The earlier period of underdeveloped stock markets was prone to instability.

Countries with more stable and strong fundamentals are said to have larger stock markets as measured in market capitalization. Figure 1a shows the market capitalization (\% of GDP) of these emerging economies over the sample period. The Czech Republic and Hungary stand out in that they have relatively high capitalization amongst others, while Slovakia has shown the lowest level of capitalization. When the transition economies are compared with developed stock markets in Figure 1b, the overall market capitalization is very low. Moreover, developed stock markets have exhibited a remarkably similar pattern among themselves with a smooth upward or downward trend over the period, whereas individual emerging markets have shown quite different

\footnotetext{
${ }^{3}$ Our focus is on the economic factors, since major political events occurred before the sample period.
} 
movements reflecting the heterogenous economic conditions. Without any discernable trend with the exception of Slovenia, Figure 1a for emerging markets is indicative of unstable macroeconomic conditions.

\section{\{Figure 1 around here\}}

The transition economies have gone through frequent exchange rate regime changes, from a fixed exchange rate regime with varying bands to managed or full floating rate systems. For example, in Hungary, from the fixed exchange rate regime narrow bands of $\pm 2.25 \%$ were introduced in March 1995, and in 2001 the bands were widened in April 2001. Poland's exchange rate system moved from a crawling peg to crawling bands in May 1995, and then in 2000 an independent floating policy was adopted. Full exchange rate flexibility was introduced in the middle of 2001. In the Czech Republic, a flexible exchange rate system was introduced in 1997. Slovakia widened the crawling bands during 1995 and moved to a managed floating system in October 1998. The varying exchange rate system may often be the cause of unstable fundamentals which are then transmitted to stock markets.

Theoretically, there is a close relationship between stock prices and exchange rates. Uncovered interest rate parity suggests that the expectations of relative currency values influence the levels of domestic and foreign interest rates. This, in turn, affects the cost of capital, and thereby the profitability of a firm, and consequently the present value of the firm may change, affecting its share price. The interaction between the two variables can also arise through the effects on price competitiveness or on input costs. Empirically, significant interrelation is found elsewhere (e.g. Abdalla and Murinde 1997, Smyth and Nandha 2003, Ajayi et al. 1998 and Moore 2007). They tend to find that 
exchange rates granger-cause stock prices. In this respect, the episode of a currency crisis in the Czech Republic seems to have increased volatility in the stock market. With a widening trade deficit and an economic slowdown the Czech koruna reached a ten month low against its currency basket in April 1997. In May 1997, the target band was abandoned and the koruna depreciated almost immediately by around $10 \%$, and, it is argued, there was a significant transmission of the currency crisis from the Czech Republic to Hungary.

Entry to the EU is potentially a major factor affecting volatility, and this is the central focus of this paper. For the new member states, joining the EU implies an advance of trade, whilst potentially facilitating commodity, capital and factor market integration among member states. In particular, new members are exposed to the increased international integration of product markets and faced with intensified competition therein (Moore and Pentecost 2006). Entry to the EU has clearly changed the landscape of both real and monetary sectors in the new EU economies.

\section{Methodology}

Following Aggarwal et al. (1999) and Hammoudeh and Li (2006), we first identify shifts in volatility with the iterated cumulative sums of squares (ICSS) algorithm. After the breakpoints of variance changes are identified, the two GARCH models are estimated, one conventional (or standard) and the other with dummy variables corresponding to the breakpoints as discovered in the ICSS. 


\subsection{ICSS algorithm}

The ICSS algorithm is used to detect discrete changes in the variance of stock returns. It is assumed that the data display a stationary variance over an initial period until a sudden change occurs resulting from a sequence of events, then the variance reverts to stationary again until another change occurs. This process is repeated through time, generating a time series of observations with an unknown number of changes in the variance.

Let $\left\{\varepsilon_{t}\right\}$ denote a series of independent observations from a normal distribution with zero mean and unconditional variance $\sigma_{t}^{2}$. The variance in each interval is denoted by $\sigma_{j}^{2}, j=0,1, \ldots \ldots N_{T}$, where $N_{T}$ is the total number of variance changes in $T$ observations. By letting $1<\kappa_{1}<\kappa_{2}<\ldots . .<\kappa_{N_{T}}<T$ the set of breakpoints, the variance is defined as

$$
\begin{gathered}
\sigma_{t}^{2}=\sigma_{0}^{2} \quad 1<t<\kappa_{1} \\
=\sigma_{1}^{2} \quad \kappa_{1}<t<\kappa_{2} \\
\ldots \\
=\sigma_{N_{T}}^{2} \quad \kappa_{N_{T}}<t<T
\end{gathered}
$$

A cumulative sum of squares is used to estimate the number of changes in variance and the point in time of each variance shift. The cumulative sum of the squared observations from the start of the series to the $k$ th point in time is expressed as

$$
C_{k}=\sum_{t=1}^{k} \varepsilon_{t}^{2} \quad \text { where } k=1, \ldots \ldots T
$$

Define the statistic $D_{k}$ as follows, 
$D_{k}=\left(C_{k} / C_{T}\right)-k / T \quad$ with $D_{0}=D_{T}=0$.

where $C_{T}$ is the sum of the squared residuals from the whole sample period.

If variance remains the same over the sample period, the statistic oscillates around zero and it can be plotted as a horizontal line against $k$. If there are sudden variance changes in the series, the statistic values drift up or down from zero. The critical values, which define the upper and lower limits for the drifts under the null hypothesis of stationary variance determine the significant change in variance of the series. If the maximum of the absolute value of the statistic $D_{k}$ is greater than the critical value, the null hypotheses of no sudden changes is rejected. Let $k^{*}$ be the value of $k$ at which $\max _{k}\left|D_{k}\right|$ is attained, and if $\max _{k} \sqrt{(T / 2)\left|D_{k}\right|}$ exceeds the critical value, then $k^{*}$ is taken as an estimate of the change point. The term $\sqrt{(T / 2)}$ is to standardize the distribution. The critical value of 1.36 is the $95^{\text {th }}$ percentile of the asymptotic distribution of $\max _{k} \sqrt{(T / 2)\left|D_{k}\right|}$. Therefore, upper and lower boundaries can be set at \pm 1.36 in the $D_{k}$ plot.

In the case of multiple change points, the $D_{k}$ function alone is not enough to identify the breakpoints. Inclan and Tiao (1994), therefore, developed an algorithm that uses the $D_{k}$ function to systematically look for change points at different points of the series. The algorithm works by evaluating the $D_{k}$ function over different time periods and those different periods are determined by break points, which are identified by the $D_{k}$ plot. Once the change points are identified using the ICSS algorithm, the periods of changes in volatility are analyzed with potential factors. 


\subsection{The GARCH model}

Having identified the change points in variance, the GARCH model is estimated without and with sudden changes in variance. The standard $\operatorname{GARCH}(1,1)$ model can be defined for the case without sudden changes as given

$x_{t}=\mu+e_{t} \quad e_{t} \mid I_{t-1} \sim N\left(0, h_{t}\right)$

$h_{t}=\omega+\alpha e_{t-1}^{2}+\beta h_{t-1}$

$N$ represents the conditional normal density with mean zero and variance $h_{t} \cdot I_{t-1}$ is the information available at $t$-1. If some series show evidence of autocorrelation, then $\operatorname{AR}(1)$ with GARCH $(1,1)$ is estimated. The GARCH model with sudden changes can be modified as

$x_{t}=\mu+e_{t} \quad e_{t} I_{t-1} \sim N\left(0, h_{t}\right)$

$h_{t}=\omega+d_{1} D_{1}+\ldots .+d_{n} D_{n}+\alpha e_{t-1}^{2}+\beta h_{t-1}$

where $D_{1} \ldots . . D_{n}$ are the dummy variables: 1 for each point of sudden change of variance onwards and 0 for otherwise. It is argued that the standard GARCH model overestimates the persistence in volatility since relevant sudden changes in variance are ignored (Lastrapes, 1989 and Lamoreux and Lastrapes, 1990). Given the modified GARCH model, which incorporates the regime shifts detected by the ICSS algorithms, the persistence of volatility, i.e. $\alpha+\beta$ is predicted to be smaller than that found by the conventional GARCH model.

\section{Data and descriptive statistics}


The dataset used in this study is the weekly Monday closing price indices of five major Central European stock markets. ${ }^{4}$ They are the Warsaw General Index of Poland, the Prague PX50 of the Czech Republic, the SAX 16 of Slovakia, the Budapest BUX of Hungary and the SBI of Slovenia. The data starts from 1994:04:11 and ends at 2006:3:27, yielding 625 observations in total for each series..$^{5}$ All the data are retrieved from Datastream, and the weekly returns are constructed as the first difference of logarithmic prices multiplied by 100 .

Stationarity in the time series is checked by applying the Augmented Dickey Fuller (ADF) test. The results fail to reject the null of a unit root in the logarithm of price series, but overwhelmingly reject the null for the first difference of logarithmic price series $^{6}$. This is consistent with much of the empirical evidence found for mature stock markets, in which the behavior of stock prices is characterized by a Martingale process.

\section{\{Table 1 around here\}}

Table 1 presents the statistical properties of the returns from the five markets. Over the sample period, the Polish market is the most volatile with the standard deviation at 4.53 percent followed by the Hungarian market with 4.01 percent, while the Slovenian market appears to be most stable with standard deviation being 2.91. In terms of average return, Hungary has the highest weekly average return of 0.41 percent, whereas Slovakia, the lowest with 0.02 percent. The distribution of returns over time is negatively skewed for the Czech Republic, Hungary and Slovakia. Almost all returns are characterized by statistically significant kurtosis, suggesting that the underlying series are leptokurtic, that is, the series have a fatter tail and a higher peak as compared with a normal distribution.

\footnotetext{
${ }^{4}$ In the case of a holiday on a Monday, the stock price on the previous day of trading was used.

${ }^{5}$ The starting data of our sample reflects the earliest data available for the Czech Republic.

${ }^{6}$ To save the space, the result is not reported here but is available from the authors upon request.
} 
Correspondingly, the Jarque-Bera test suggests that the distribution of returns is nonnormal. In Table 1, we also report the Ljung-Box Q-statistic for the sixteenth orders in the levels and squares of the residuals. Apart from the case of Hungary, where the LjungBox Q-statistic indicates serial correlation in level, there is no serial correlation in other return series, but the squared residuals do show serial correlation, suggesting the existence of volatility clustering of an $\mathrm{ARCH}$ process in these series.

\section{Empirical results}

\subsection{Sudden changes in variance}

Based on ICSS algorithm, Figure 2 plots the return for each series with the points of sudden changes and \pm 3 standard deviations. The result shows that switching points range from five to nine shifts for these emerging markets ${ }^{7}$. Note that the volatility decreases mean that the markets return to a tranquil period, and that our explanation will focus on the volatility increases. Discussion begins with overall results, and then moves on to individual specific features. See Table 2 for the date of switching points and economic events.

\section{\{Figure 2 around here\}}

\section{\{Table 2 around here\}}

In the earlier period of transition in 1994, a high level of variance is observed with the exception of Hungary, reflecting unstable stock markets. However, as they approach entry to the EU in 2004, the magnitude of the volatility decreases, or at least there is no sign of increase in volatility, except for a sudden short-lived increase in 2005 in Slovakia.

\footnotetext{
${ }^{7}$ Hammoudeh and Li (2006) have found from three to eight sudden changes for Gulf Arab stock markets from 1994 to 2001.
} 
Poland and Slovenia have shown a gradual decline over the period. In this respect, the economic integration within the EU may have brought about some stability in stock returns for these economies.

Generally, after the Asian crisis in 1997 and during the Russian crisis in 1998, sudden increases in volatility, though of varying magnitude, are observed. This result emphasizes the fact that these emerging markets were exposed to volatility related to the occurrence of economic events in Asia and Russia. Prior to transition, the Russian economy in particular had a dominant role in these economies, and the Russian crisis may have aggravated these emerging stock markets, causing sudden shifts. Hungary and the Czech Republic, especially so with a sharp increase in volatility around 1998, seem to be strongly affected. In the case of the Czech Republic, the propagation mechanism from the Asian and Russian crises may be compounded by their own currency crises.

Hammoudeh and $\mathrm{Li}$ (2006) found that the terrorist attack on $11^{\text {th }}$ September 2001 exerted sudden shifts in Gulf Arab stock markets using the same methodology. The impact of such external factors seems to be zero in our sample, as the level of volatility remains to be tranquil in all cases. This may be due to the low integration of these emerging markets within world markets. There is no impact from the Gulf War in 2003, either. The following are the country specific features.

Poland: It has revealed five regime shifts. The initial volatility is the highest amongst other countries, followed by a rapid fall. This movement corresponds to exchange rate regime shifts. Poland had a crawling peg system until 1994, then in May 1995 moved to a crawling band regime with bands of more than $\pm 7 \%$. During this period, the volatility of nominal exchange rates has significantly fallen from $14.5 \%$ in 
1994 to $9.5 \%$ in 1995 . This seems to have led to a sudden fall in stock return volatility in 1995. The sudden increase in 1998 is related to the breakout of the Asian and Russian financial crises. During a relatively stable period when volatility was in decline from 1999 onward, exchange rates were floated in 2000 and entry to the EU was accomplished in 2004.

The Czech Republic: The Czech Republic also experiences five sudden shifts in volatility. A sudden fall in 1995 also corresponds to the exchange rate regime shifts: from the fixed regime the crawling band was introduced. The next sudden change is an increase in volatility in 1997-1998. This should be largely the consequence of the currency crisis that originated in May 1997 when speculative pressure forced the Czech Republic to abandon its exchange rate peg, and the exchange rate depreciated by about $10 \%$ below the original parity. A fall in volatility in 1999 may be attributed to the effect of an inflation targeting policy implemented in 1998, lowering the inflation rate from $10.7 \%$ in 1998 to $2.1 \%$ in 1999 , thus stabilizing the fundamentals.

Hungary: Hungary starts with a tranquil period, which seems to reflect a relatively stable stock market. Strictly speaking, Hungary is not an emerging market because some listed companies already have more than 100 years of active history (Poshakwale and Murinde, 2001). While the perverse effect of the Asian crisis in 1997 does not seem to be apparent as the volatility falls into a period of calm, the spillover effects of the Russian and Czech crises are identified with a large increase in volatility in 1998. The sudden shifts in 1998 (and also in 1996) may also be associated with a dramatic development in company performance and foreign direct investment in Hungary: Net profits of companies listed on the stock exchange increased by around 
170\% between 1993 and 1996, foreign direct investments amounted to $\$ 14$ billion, market capitalization reached more than $\$ 14.8$ billion, and daily equity turnover increased significantly to reach $\$ 88$ million in 1997-1998 (Poshakwale and Murinde 2001). Since 2000, the tranquil period remains throughout the entry phase to the EU.

Slovakia: Followed by an initial sudden jump, volatility falls sharply. The plot then displays two short-lived sudden jumps in 1995 and in 2005 and a moderate increase in 1997. The sudden change in 1995 coincides with the fact that a fixed exchange rate regime was switched to a crawling band system. The increase in 1997 appears to be the consequence of the impact of the Asian financial crises. A relatively low sensitivity to external factors may be explained by a relatively small stock market with low market capitalization (see Figure 1a).

Slovenia: Sudden shifts are frequently observed with nine change points, though within a narrow scale of $\pm 20 \%$ as compared with other emerging markets in the current study. Unlike other emerging countries, the exchange rate regime (the managed floating system) remained the same over the sample period. The high volatility is skewed in the earlier sample period. Slovenia experienced high instability in macroeconomic variables at the outset of the transition period, for example the lending rate and the rate of inflation were as high as $200 \%$ in 1992 . A decline in stock return volatility in 1995 is, therefore, possibly related to a drastic fall in these variables: the lending rate, inflation and exchange rate volatility fell from 39\%, 21\% and 15\% respectively in 1994 to $23.4 \%, 13 \%$ and $2 \%$ in 1995. The effects of the Asian and Russian crises are also evident with sudden changes. A fall in volatility in 2004 appears to be manifest during entry to the EU and the European Rate Mechanism (ERM2). 


\subsection{GARCH models and sudden changes in variance}

We now further examine the volatility persistence of these markets. The problem with Inclan and Tiao (1994)'s ICSS approach is that the critical value, which is 1.36 at the 5 percent level, is derived under the null of independently distributed normal shocks. If the data generating process is a GARCH process, the critical value will be considerably larger due to volatility clustering induced by the GARCH model. ${ }^{8}$ Some of the regime shifts seem to be short-lived and are most likely the result of outlier impact. To determine which change points are statistically significant and how these regime shifts can affect persistence in volatility, we estimate the GARCH model three times: once without regime shifts as shown in equation 3; once with all of the sudden changes detected by ICSS in variance and once by incorporating only significant changing points of variance. Table 3 reports the estimated results. The left-hand panel of this table is the result from the standard GARCH model; it shows that all the GARCH parameters are statistically significant at least at a 5 percent significance level. The persistence of shocks $(\alpha+\beta)$ appears to be very high, being close to unity, especially for Slovenia at one, which represents the IGARCH effect, i.e. shocks have a permanent effect on the variance of the return. The results, with all sudden changes and with significant sudden changes only in variance, are displayed in the middle and right-hand panels of the table. It shows that there is no significant difference between these two panels of results, suggesting that the insignificant changing points might be overestimated by ICSS approach. Now focus on the right-hand panel of the table, as predicted, the persistence of the volatility $(\alpha+\beta)$ is considerably reduced in all cases. Among others, Slovakia shows the largest decline in

\footnotetext{
${ }^{8}$ We thank the anonymous referee who pointed out this problem.
} 
volatility persistence by 67.3 percent, followed by Poland with a 58.3 percent reduction, and then Slovenia with 54.0 percent, the Czech Repuplic with 46.3 percent and finally Hungary with 36.5 percent. The most interesting case is Slovenia, as the persistence is only 0.46 when dummy variables are included in the variance equation. Overall, our results are consistent with Lastrapes (1989) and Lamoureux and Lastrapes (1990) who argue that persistence in volatility is overestimated when standard GARCH models are applied to a series with the presence of sudden changes in variance.

\section{\{Table 3 around here $\}$}

Finally, included in Table 3 are the ARCH LM test and Ljung-Box statistics

performed on standardized residuals $\varepsilon_{t} / \sqrt{h_{t}}$. It reveals that there is no ARCH effect or autocorrelation in the residual series.

\section{Conclusions}

This paper investigates sudden shifts of volatility and re-examines volatility persistence for the stock markets of new EU members during the period 1994-2006. With the ICSS algorithm methodology, the time path of volatility in returns appears to be effectively identified for these transition economies.

In this paper, sudden shifts are largely explained by domestic, economic and financial factors, and also they are more likely to be the major causes behind the shifts. This finding is consistent with that of Aggarwal et al (1999) who find strong countryspecific factors for emerging Asian and Latin American stock markets. This is contrasted with the findings of Hammoudeh and Li (2006) who find that major global events are the dominant factors for Gulf Arab stock markets. In common to these studies and also those 
of Ewing and Malik (2005) and Malik (2003), when the sudden shifts are incorporated in the GARCH model, the persistence of volatility has considerably reduced.

It is argued that the development of stock markets for these transition economies provides a vehicle for mobilizing household savings more for equity finance hence favoring the corporate sector. This is also important for promoting international capital flows. This also enables firms to have less reliance on debt finance, reducing the risk of a credit crunch, while creating a less risky financial structure. These transition economies, therefore, face an imperative issue of establishing stable stock markets, while shifting policy towards integration with the European Union. Although high volatility is found by several shifts in the earlier period, as the integration process with the EU proceeds, sudden changes have declined, accompanied by a downward trend in volatility. The important implication is that joining the EU may be a contributory factor to stabilizing the stock markets of these transition economies.

\section{Acknowledgements}

We thank an anonymous referee of this Journal for helpful comments and suggestions on earlier versions of this paper. Any errors and/or omissions, however, are our own. 


\section{References}

Abdalla, I., Murinde, V., 1997. Exchange rate and stock price interactions in emerging financial markets: evidence of India, Korea, Pakistan and the Philippines. Applied Financial Economics 7, 25-35.

Aggarwal, R., Inclan, C., Leal, R., 1999. Volatility in emerging stock markets. Journal of Financial and Quantitative Analysis 34, 33-55.

Ajayi, R.A., Friedman, J., Mehdian, S.M., 1998. On the relationship between stock returns and exchange rates: tests of Granger causality. Global Finance Journal 9, 241-251.

Ewing, B. T., Malik, F., 2005. Re-examining the asymmetric predictability of conditional variances: the role of sudden changes in variance. Journal of Banking and Finance $29,2655-2673$.

Hammoudeh, S., Li, H., 2006. Sudden changes in volatility in emerging markets: the case of Gulf Arab stock markets. International Review of Financial Analysis, March (in press).

Inclan, C., Tiao, G.C., 1994. Use of cumulative sums of squares for retrospective detection of changes of variance. Journal of the American Statistical Association 89, 913-923.

Kim, S.J., Moshirian, F., Wu, E., 2005. Dynamic stock market integration driven by the European Monetary Union: an empirical analysis. Journal of Banking and Finance $29,2475-2502$ 
Lamoureux, C.G., Lastrapes, W.D., 1990. Persistence in variance, structural change and the GARCH model. Journal of Business and Economic Statistics 68, 225-234.

Lastrapes, W.D., 1989. Exchange rate volatility and U.S. monetary policy: an ARCH application. Journal of Money, Credit and Banking 21, 66-77.

Malik, F., 2003. Sudden changes in variance and volatility persistence in foreign exchange markets. Journal of Multinational Financial Management 13, 217-230.

Moore, T., 2007. The Euro and stock markets in Hungary, Poland and UK. Journal of Economic Integration, 22(1), 69-90.

Moore, T., Pentecost, E. J., 2006. An investigation into the sources of fluctuation in real and nominal wage rates in eight EU countries: A structural VAR approach. Journal of Comparative Economics 34, 357-276.

Morana, C., Beltratti, A., 2002. The effects of the introduction of the euro on the volatility of European stock markets. Journal of Banking and Finance 26, 20472064.

Poshakwale, S., Murinde, V., 2001. Modelling the volatility in East European emerging stock markets: evidence on Hungary and Poland. Applied Financial Economics 11, 445-456.

Smyth, R., Nandha, M., 2003. Bivariate causality between exchange rates and stock prices in South Asia. Applied Economics Letters 10, 699-704.

Westermann, F., 2004. Does the Euro affect the dynamic interactions of stock markets in Europe? evidence from France, Germany and Italy. European Journal of Finance $10,139-148$. 
Table 1 Descriptive statistics

\begin{tabular}{lllrlrrr}
\hline & & & Excess & Jarque- & \\
Country & Mean & Std. D & Skewness & Kurtosis & \multicolumn{1}{c}{ Bera } & Q(16) & $\mathrm{Q}^{2}(16)$ \\
\hline Poland & 0.1936 & 4.5389 & 0.0145 & 4.6380 & 559.30 & 23.10 & 465.09 \\
Czech Republic & 0.0689 & 3.0987 & -0.6672 & 2.6561 & 229.72 & 17.63 & 74.42 \\
Hungary & 0.4089 & 4.0051 & -0.1808 & 5.7454 & 861.66 & 44.31 & 307.41 \\
Slovenia & 0.1809 & 2.9050 & 0.5811 & 6.3748 & 1091.70 & 26.85 & 166.64 \\
\hline Slovakia & 0.0178 & 3.3069 & -0.1662 & 6.8117 & 1209.26 & 18.07 & 239.28 \\
\hline
\end{tabular}

Note: $\mathrm{Q}(16)$ and $\mathrm{Q}^{2}(16)$ are the Ljung-Box Q-statistic for the $16^{\text {th }}$ orders in the levels and squares of the returns, respectively. Under the hypothesis of no serial correlation, the critical value is 26.30 at the $5 \%$ level. 
Table 2 Sudden changes in volatility

\begin{tabular}{|c|c|c|c|}
\hline $\begin{array}{l}\text { The market } \\
\text { (No of change } \\
\text { points) }\end{array}$ & Period & Std.dev & Events \\
\hline \multirow[t]{6}{*}{ Poland (5) } & April 11, 1994 - July 11, 1994 & $14.30^{*}$ & \\
\hline & July 18, 1994- May22,1995 & 7.52 & \\
\hline & May 29,1995 - May 18, 1998 & $4.15^{*}$ & $\begin{array}{l}\text { Crawling band regime in May } 1995 \\
\text { from crawling pegs during } 1994 . \\
\text { Asia crisis }\end{array}$ \\
\hline & May 25, 1998- January 25, 1999 & 7.33 & Russian crisis. \\
\hline & $\begin{array}{l}\text { February 1, 1999- December 31, } \\
2001\end{array}$ & $3.64 *$ & $\begin{array}{l}\text { Independent floating exchange rate } \\
\text { policy in June } 2000 .\end{array}$ \\
\hline & January 7, 2002- March 27, 2006 & $2.46^{*}$ & Entry to the EU in 2004 \\
\hline \multirow[t]{6}{*}{ Czech Rep. (5) } & April 11, 1994 -March 13, 1995 & 4.58 & \\
\hline & March 20, 1995-January 27, 1997 & $1.79 *$ & $\begin{array}{l}\text { Crawling band in February } 1996 \text {, } \\
\text { from a fixed regime. }\end{array}$ \\
\hline & $\begin{array}{l}\text { February 3, 1997-August 17, } \\
1998\end{array}$ & $2.74^{*}$ & $\begin{array}{l}\text { Currency crisis in May } 1997 \\
\text { followed by a flexible exchange } \\
\text { rate regime. } \\
\text { Asian and Russian currency crises }\end{array}$ \\
\hline & August 24, 1998-May 17, 1999 & 5.31 & \\
\hline & $\begin{array}{l}\text { May 24, 1998-November } 12 \text {, } \\
2001\end{array}$ & $3.47 *$ & Inflation targeting policy in 1998 \\
\hline & $\begin{array}{l}\text { November 19, 2001- March 27, } \\
2006\end{array}$ & $2.46^{*}$ & Entry to the EU in 2004 \\
\hline \multirow[t]{6}{*}{ Hungary (5) } & $\begin{array}{l}\text { April 11, 1994-December 25, } \\
1995\end{array}$ & $2.78^{*}$ & $\begin{array}{l}\text { Crawling pegs with bands from a } \\
\text { fixed exchange rate regime in } \\
\text { March } 1995 .\end{array}$ \\
\hline & January 1, 1996-March 11, 1996 & 7.36 & $\begin{array}{l}\text { Rapid increase in net profits of } \\
\text { listed companies. }\end{array}$ \\
\hline & March 18, 1996 - May 4, 1998 & $3.74 *$ & $\begin{array}{l}\text { Rapid increase in FDI and market } \\
\text { capitalization in 1997-1998. } \\
\text { Asian crisis. }\end{array}$ \\
\hline & May 11, 1998- October 26, 1998 & $10.67 *$ & Russian crisis. \\
\hline & $\begin{array}{l}\text { November 2, 1998- December 4, } \\
2000\end{array}$ & $4.59 *$ & \\
\hline & $\begin{array}{l}\text { December 11, } 2000 \text { - March 27, } \\
2006\end{array}$ & $2.86^{*}$ & $\begin{array}{l}\text { Crawling bands widened in April } \\
2001 . \\
\text { Entry to the EU in } 2004\end{array}$ \\
\hline \multirow[t]{6}{*}{ Slovakia (7) } & April 11, 1994-July 4, 1994 & $11.15^{*}$ & \\
\hline & July 11, 1994-December 19, 94 & $2.88^{*}$ & \\
\hline & December 26, 94-January 2, 1995 & 10.16 & \\
\hline & $\begin{array}{l}\text { January 9, 1995-November 24, } \\
1997\end{array}$ & $2.34 *$ & $\begin{array}{l}\text { Crawling bands system from a fixed } \\
\text { exchange rate regime. }\end{array}$ \\
\hline & $\begin{array}{l}\text { December 1, 1997-October 23, } \\
2000\end{array}$ & $3.66^{*}$ & $\begin{array}{l}\text { Asian and Russian currency crises. } \\
\text { Managed floating system in Oct. } \\
1998 .\end{array}$ \\
\hline & $\begin{array}{l}\text { October 30, 2000-January 31, } \\
2005\end{array}$ & $2.46^{*}$ & Entry to the EU in 2004. \\
\hline
\end{tabular}




\begin{tabular}{|c|c|c|c|}
\hline & February 7, 2005-March 28, 2005 & 6.57 & \\
\hline & April 4, 2005 - March 27, 2006 & $1.97 *$ & \\
\hline \multirow[t]{10}{*}{ Slovenia (9) } & $\begin{array}{l}\text { April 11, 1994-November 14, } \\
1994\end{array}$ & $4.82 *$ & \\
\hline & $\begin{array}{l}\text { November 21, 1994- March, 18, } \\
1996\end{array}$ & $3.18^{*}$ & $\begin{array}{l}\text { A drastic fall in interest rates, } \\
\text { inflation and exchange rate } \\
\text { volatility in 1994-1995. }\end{array}$ \\
\hline & March, 25, 1996- July 21, 1997 & 5.70 & \\
\hline & July 28, 1997- June 29, 1998 & $2.30 *$ & Asian crisis \\
\hline & July 6, 1998- July 13,1998 & $4.83^{*}$ & Russian crisis \\
\hline & July 20, 1998 -March, 22, 1999 & $2.73 *$ & \\
\hline & March, 29, 1999-August 12, 2002 & 1.56 & \\
\hline & $\begin{array}{l}\text { August 19, 2002-October } 14, \\
2002\end{array}$ & $4.98^{*}$ & \\
\hline & October 21, 2002-May 31, 2004 & 1.70 & Entry to the EU in 2004 \\
\hline & June 7, 2004- March 27, 2006 & 1.04 & $\begin{array}{l}\text { Entry to the Exchange Rate } \\
\text { Mechanism in June } 2004 .\end{array}$ \\
\hline
\end{tabular}

Note: * Significant dummy variables above the 5\% level in the GARCH model. Time periods were detected by ICSS algorithm. 
Table 3 GARCH $(1,1)$ parameters with and without dummy variables for sudden changes in variance

\begin{tabular}{|c|c|c|c|c|c|c|c|c|c|c|c|c|c|c|c|}
\hline \multirow[b]{2}{*}{ Country } & \multicolumn{5}{|c|}{ GARCH $(1,1)$ without dummy variables } & \multicolumn{5}{|c|}{ GARCH $(1,1)$ with all dummies } & \multicolumn{5}{|c|}{ GARCH $(1,1)$ with significant dummies } \\
\hline & $\alpha$ & $\beta$ & $\alpha+\beta$ & $\mathrm{TR}^{2}$ & $\mathrm{Q}(16)$ & $\alpha$ & $\beta$ & $\alpha+\beta$ & $\mathrm{TR}^{2}$ & $\mathrm{Q}(16)$ & $\alpha$ & $\beta$ & $\alpha+\beta$ & $\mathrm{TR}^{2}$ & $\mathrm{Q}(16)$ \\
\hline Poland & $\begin{array}{l}0.0606 * * \\
(0.0183)\end{array}$ & $\begin{array}{l}0.9307 * * \\
(0.0195)\end{array}$ & 0.991 & 10.71 & 11.59 & $\begin{array}{l}0.0176 \\
(0.0318)\end{array}$ & $\begin{array}{l}0.3956 * * \\
(0.1469)\end{array}$ & 0.413 & 11.52 & 13.32 & $\begin{array}{l}0.0174 \\
(0.035)\end{array}$ & $\begin{array}{l}0.3953 * * \\
(0.0632)\end{array}$ & 0.413 & 11.49 & 13.30 \\
\hline Czech Rep. & $\begin{array}{l}0.3534 * * \\
(0.0917)\end{array}$ & $\begin{array}{l}0.4656 * * \\
(0.1398)\end{array}$ & 0.819 & 10.39 & 22.32 & $\begin{array}{l}0.1214 * * \\
(0.0609)\end{array}$ & $\begin{array}{l}0.3274 * * \\
(0.1357)\end{array}$ & 0.449 & 9.45 & 17.39 & $\begin{array}{l}0.1147 * * \\
(0.0582)\end{array}$ & $\begin{array}{l}0.3253 * * \\
(0.1357)\end{array}$ & 0.440 & 9.31 & 17.33 \\
\hline Hungary & $\begin{array}{l}0.1563 * * \\
(0.0500)\end{array}$ & $\begin{array}{l}0.7366 * * \\
(0.0928)\end{array}$ & 0.893 & 16.36 & 19.91 & $\begin{array}{l}0.0788^{*} \\
(0.0404)\end{array}$ & $\begin{array}{l}0.4883 * * \\
(0.0568)\end{array}$ & 0.527 & 19.09 & 10.58 & $\begin{array}{l}0.0788^{*} \\
(0.0426)\end{array}$ & $\begin{array}{l}0.4883 * * \\
(0.0639)\end{array}$ & 0.567 & 19.09 & 10.58 \\
\hline Slovenia & $\begin{array}{l}0.1156 * * \\
(0.0283)\end{array}$ & $\begin{array}{l}0.8883 * * \\
(0.0230)\end{array}$ & 1.004 & 7.99 & 15.90 & $\begin{array}{l}0.0243 \\
(0.0461)\end{array}$ & $\begin{array}{l}0.4223 * * \\
(0.0844)\end{array}$ & 0.447 & 19.97 & 13.82 & $\begin{array}{l}0.0188 \\
(0.0427)\end{array}$ & $\begin{array}{l}0.4430 * * \\
(0.1232)\end{array}$ & 0.462 & 20.54 & 14.51 \\
\hline Slovakia & $\begin{array}{l}0.2089 * * \\
(0.0594)\end{array}$ & $\begin{array}{l}0.6046 * * \\
(0.1070)\end{array}$ & 0.814 & 13.52 & 18.73 & $\begin{array}{l}0.0737 * * \\
(0.0308)\end{array}$ & $\begin{array}{l}0.1723 * * \\
(0.0058)\end{array}$ & 0.246 & 22.31 & 22.27 & $\begin{array}{l}0.0821 * * \\
(0.0416)\end{array}$ & $\begin{array}{l}0.1835 \\
(0.1484)\end{array}$ & 0.266 & 22.17 & 22.35 \\
\hline
\end{tabular}

Note: Standard deviations in parentheses. ** Significant above 5\% level; $\alpha$ is the coefficient for the previous shocks and $\beta$ for the persistence. Q(16) is the Ljung-Box Q-statistic for the $16^{\text {th }}$ order in the standardized residuals with the critical value 26.30 at the $5 \%$ level. TR2 is an ARCH LM test for autoregressive conditional heteroskesdasticity up to order 16. 
Figure 1a Market capitalization for new EU stock markets (\% of GDP)

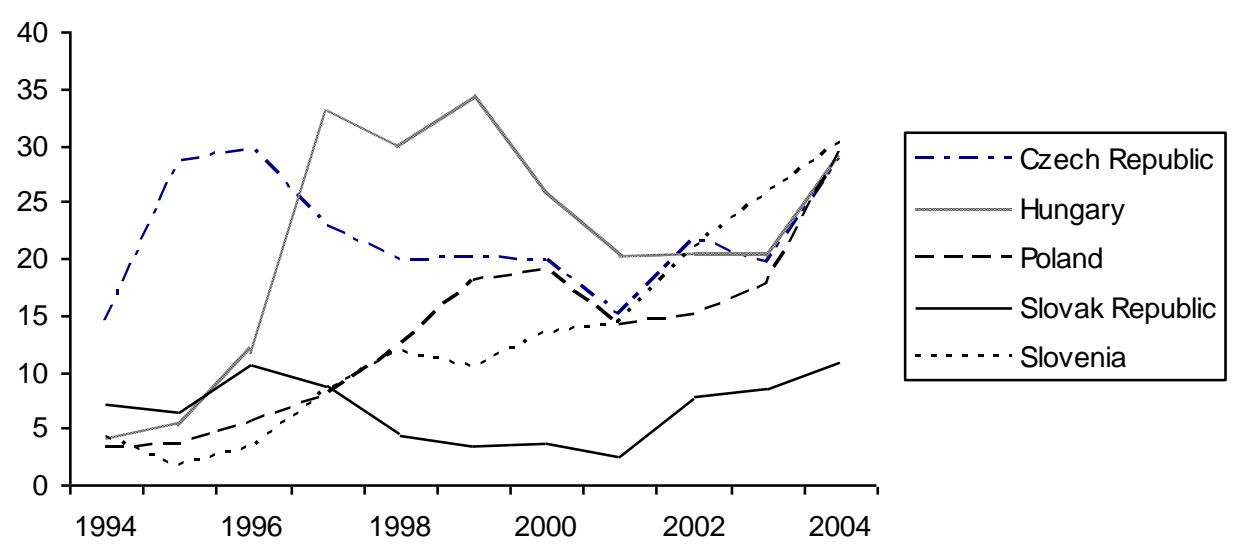

Sources: World Development Indicators

Figure 1b Market capitalization for developed stock markets (\% of GDP)

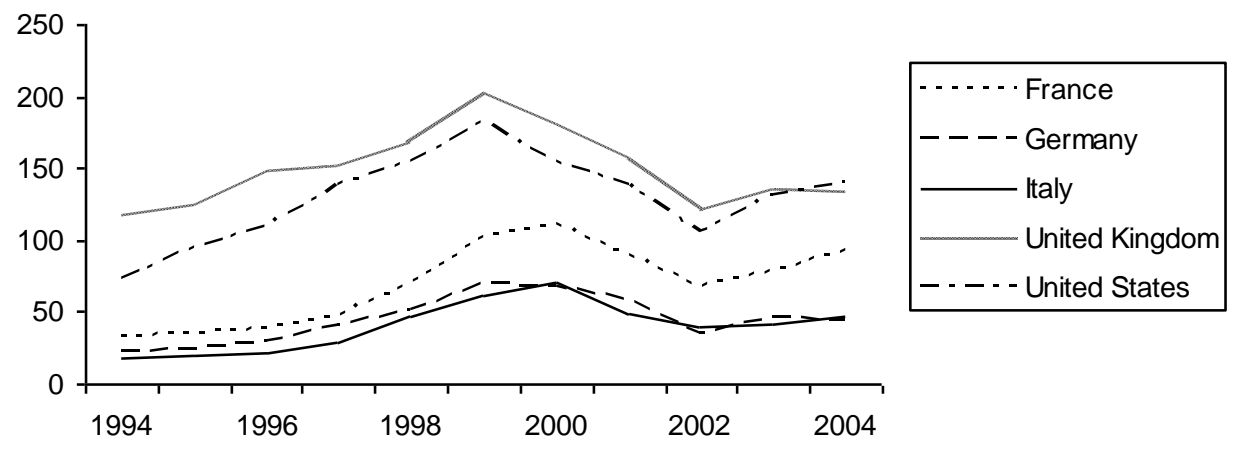

Sources: World Development Indicators 
Figure 2 Weekly returns for the five new EU stock returns and regime shifts in volatility (Bands are at \pm 3 standard deviation. Change points are estimated using ICSS algorithm.)

(a) Poland

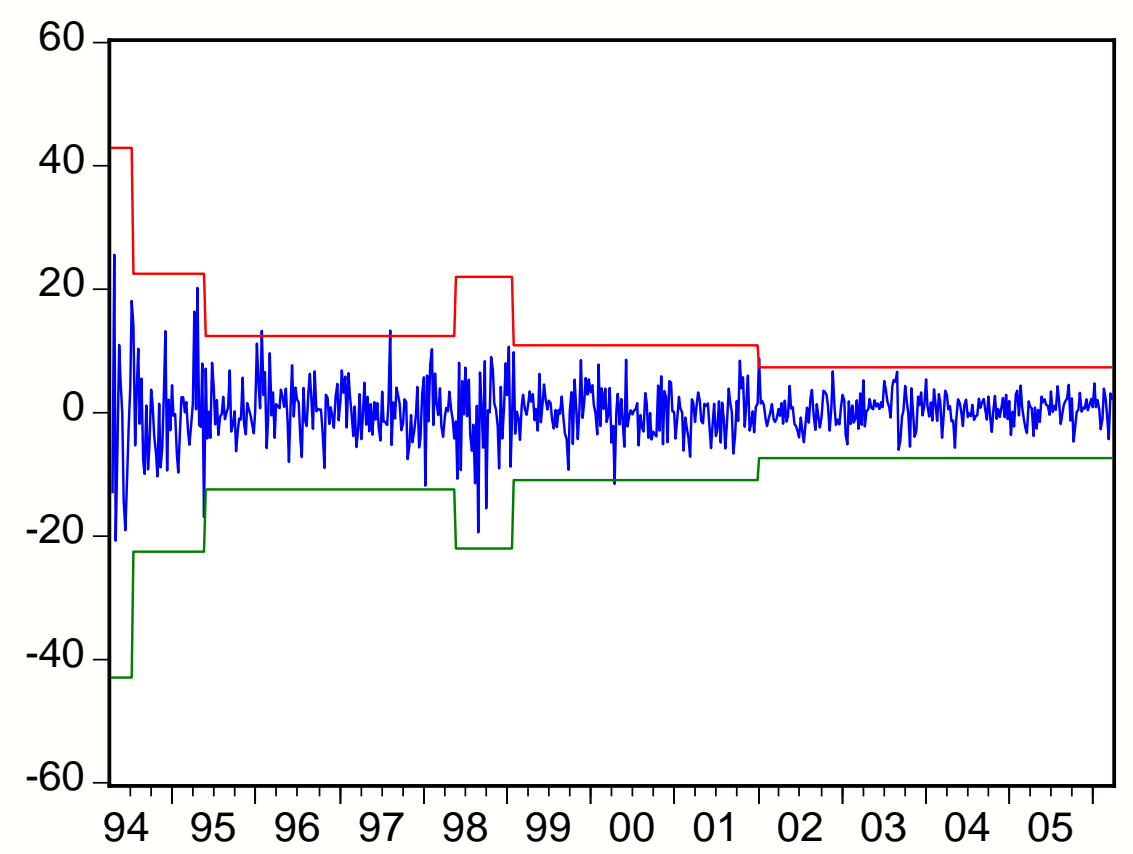

(b) The Czech Republic

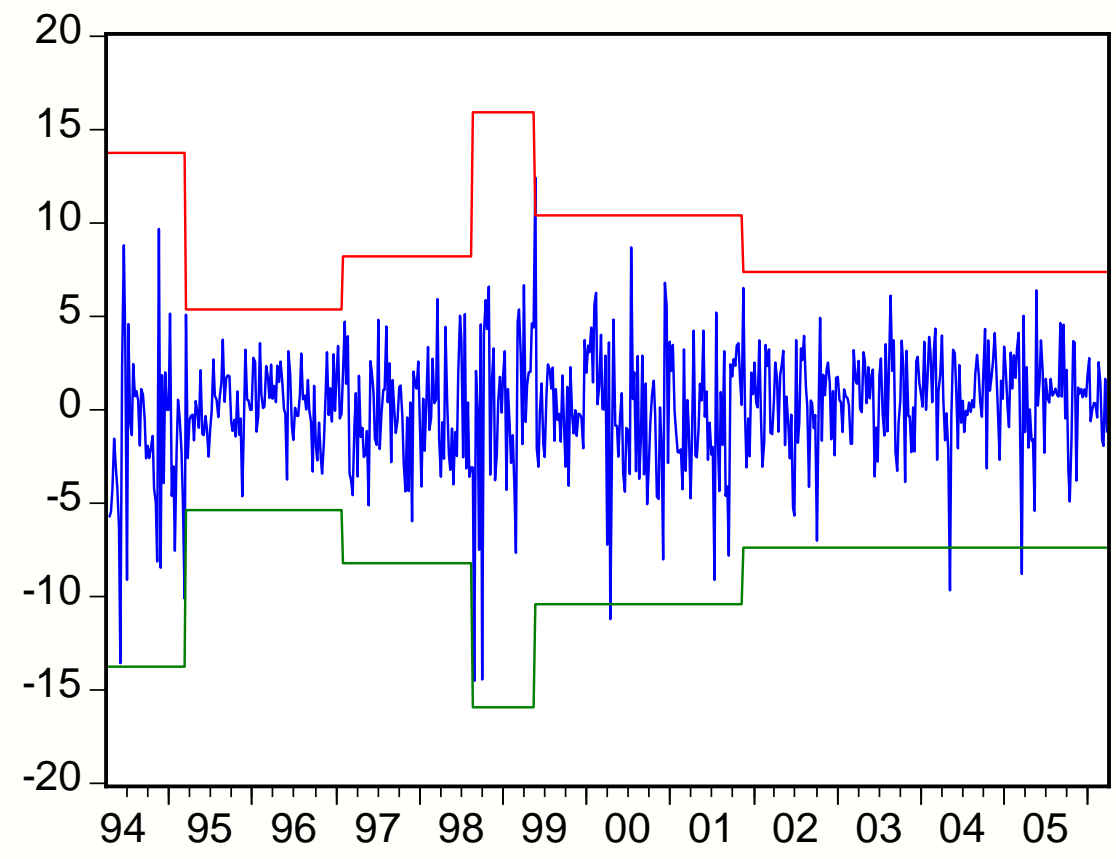


(c) Hungary

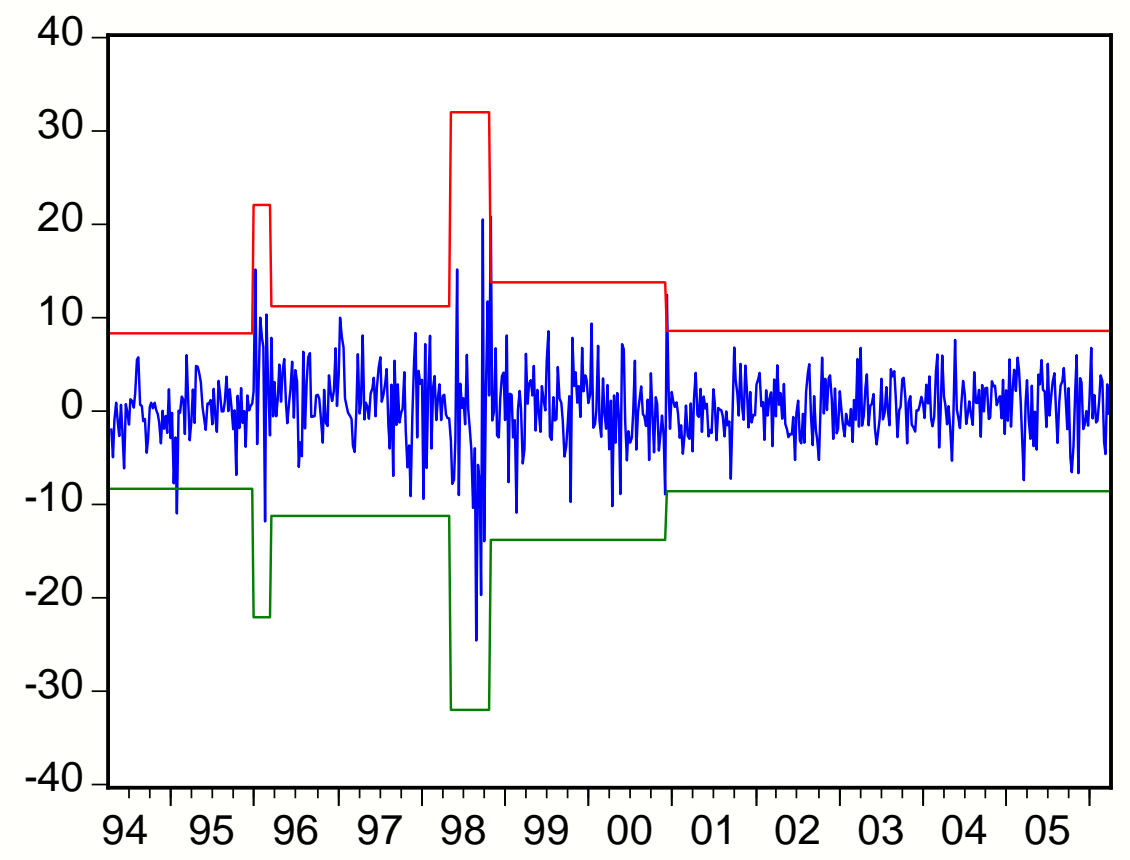

(d) Slovakia

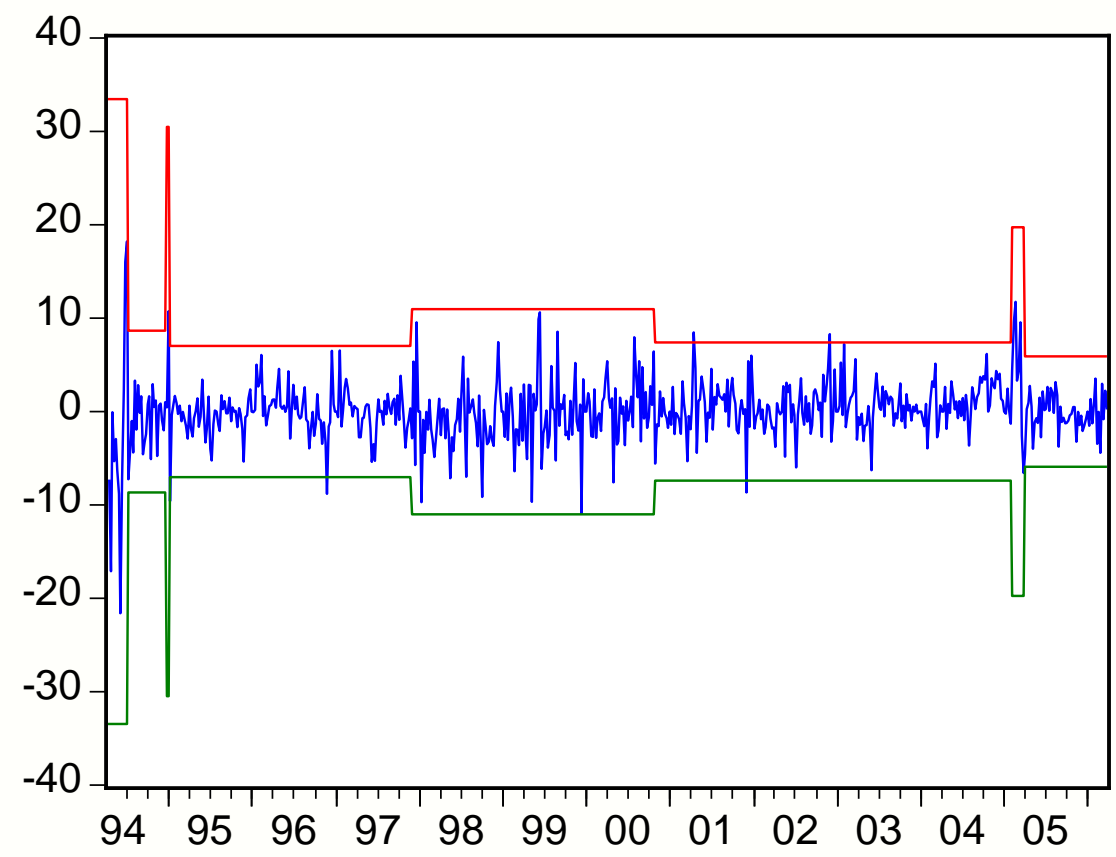


(e) Slovenia

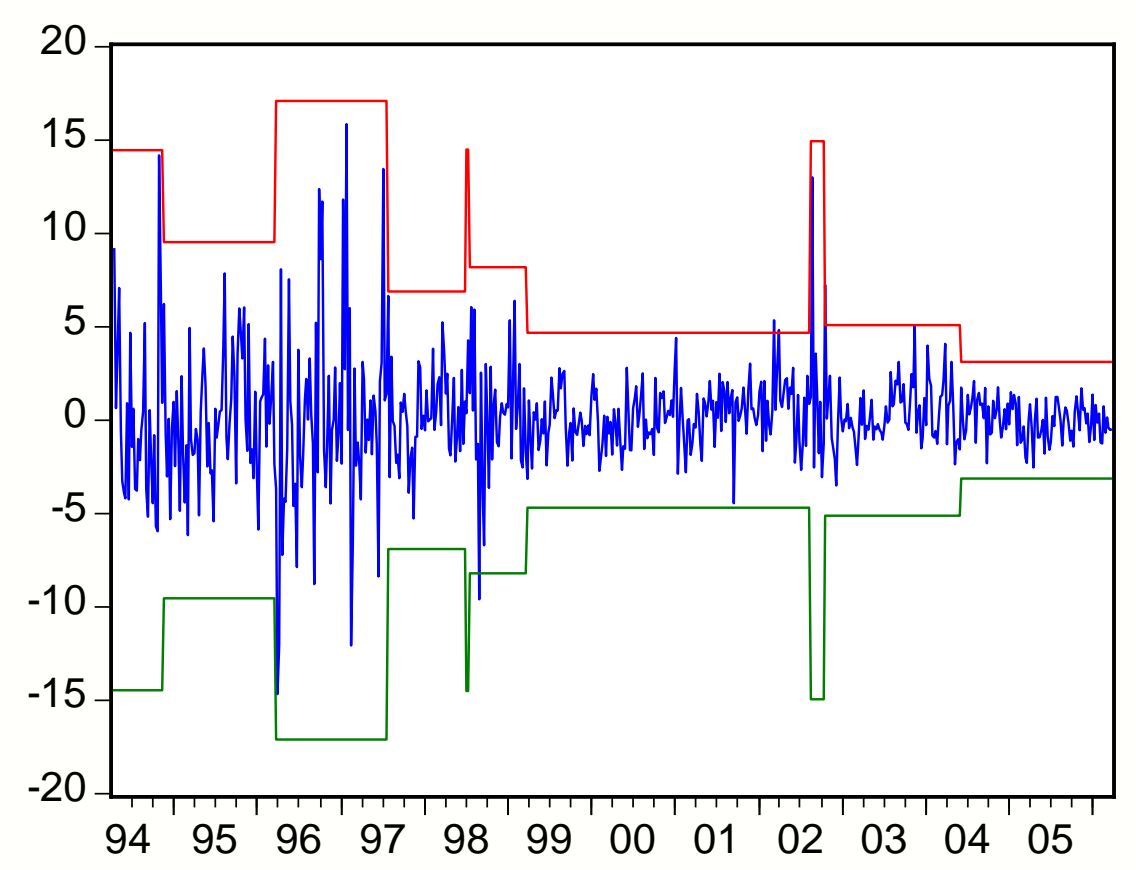

